\title{
Carcinoid lung: diffuse pulmonary infiltration by a multifocal bronchial carcinoid
}

\author{
C. SK I N N ER a nd S. W. B. E W E N \\ Northern General Hospital, Sheffield, and Department of Pathology, University of Aberdeen
}

\begin{abstract}
Skinner, C. and Ewen, S. W. B. (1976). Thorax, 31, 212-219. Carcinoid lung: diffuse pulmonary infiltration by a multifocal bronchial carcinoid. A 20 -year-old student presented with diarrhoea and miliary mottling in the chest radiograph. Biopsy specimens of lung and cervical lymph node showed diffuse multifocal carcinoid tumour. No deterioration in clinical state, radiographic appearances or lung function has occurred after two years' treatment with melphalan.
\end{abstract}

The differential diagnosis of diffuse radiographic pulmonary abnormality includes a large number of conditions (Robin, 1970), but widespread infiltration by a 'carcinoid' tumour of low-grade malignancy in a young man with no history of respiratory illness has not been described. The present case was associated with stromal amyloid deposition, in common with a previous similar case report in which the patient had been exposed to noxious fumes (Gordon, Miller, and Mittman, 1973).

\section{CASE REPORT}

A 20-year-old student was referred to the medical outpatient department in January 1973 with a complaint of intermittent watery diarrhoea for six months and a loss of $6 \mathrm{~kg}$ in weight. $\mathrm{He}$ had no respiratory symptoms and his general condition was normal. Sigmoidoscopy showed an oedematous mucosa which tended to bleed easily, and barium enema examination showed severe spasm throughout the colon. The haemogloblin was $16.1 \mathrm{~g} / \mathrm{dl}$ and erythrocyte sedimentation rate $2 \mathrm{~mm}$ in the first hour. The chest radiograph (Fig. 1) showed fairly well defined, moderately dense, diffuse miliary changes, and there was no evidence of mediastinal enlargement. Pulmonary function tests (Table I) showed a mild restrictive ventilatory defect, reduced single-breath transfer factor (TF), and slight hypoxaemia. A tuberculin test was weakly positive (he had received BCG vaccination in 1965). A Kveim test was not performed. Serological tests for farmer's lung and bird fancier's lung were negative as were tests for rheumatoid factor, antinuclear antibodies, and antimitochondrial antibodies. At this time the $\vec{\theta}$ provisional diagnosis was spastic colon and unrelated pulmonary sarcoidosis. The diarrhoea responded to symptomatic treatment with diphenoxylate and he has been reviewed regularly.

In July 1973 he was noted to have a number of small, mobile, firm nodules up to $10 \mathrm{~mm}$ diameter®్ (apparently lymph nodes) in both cervical regions. An excision biopsy specimen of one of these waso taken.

HISTOLOGY OF NECK BIOPSY SPECIMEN The specimen consists of a nodule extensively infiltratedo by groups of polygonal cells separated by abun- $\frac{0}{x}$ dant stroma (Fig. 2). No residual lymphoid tissueo is visible. The cytoplasm of most cells is granular and several foci of calcification are present in theo stroma and between tumour cells. There are two histological patterns within the tumour, eithero solid aggregates of cells with vesicular nuclei, or an acinar, rosette appearance in which the nucle? are more elongated and solid. Mitotic figures haven not been identified in many sections, and there is minimal nuclear aberration although the occasional large bizarre hyperchromatic nucleus is present. The specimen is a deposit from a tumouro of low-grade malignancy, and although the tissue of origin cannot be identified, the tumour is $\mathrm{re}$ garded as a neural crest derivative.

As the exact situation of the primary tumouro could not be determined on histological ground $\bar{\rho}$ alone, an open lung biopsy was performed through a right thoracotomy. At operation the lung was studded with small, firm, white nodules up to $2 \mathrm{~mm}$ diameter, some of which showed a centraf 


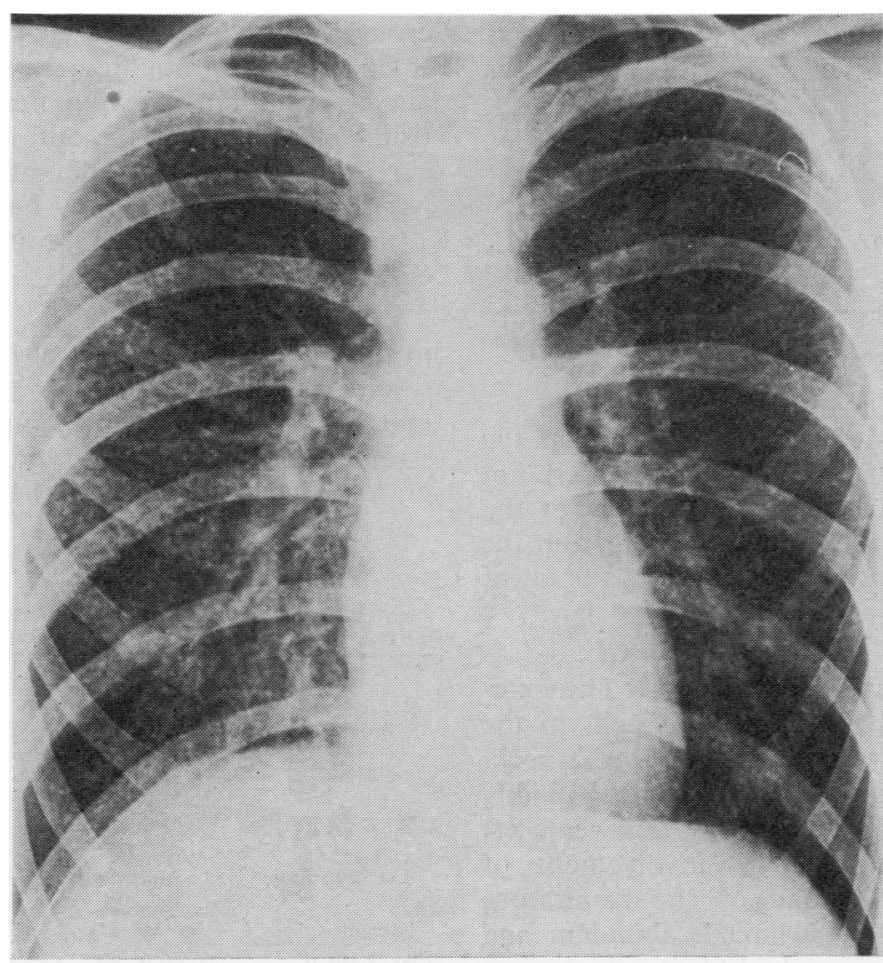

(a)

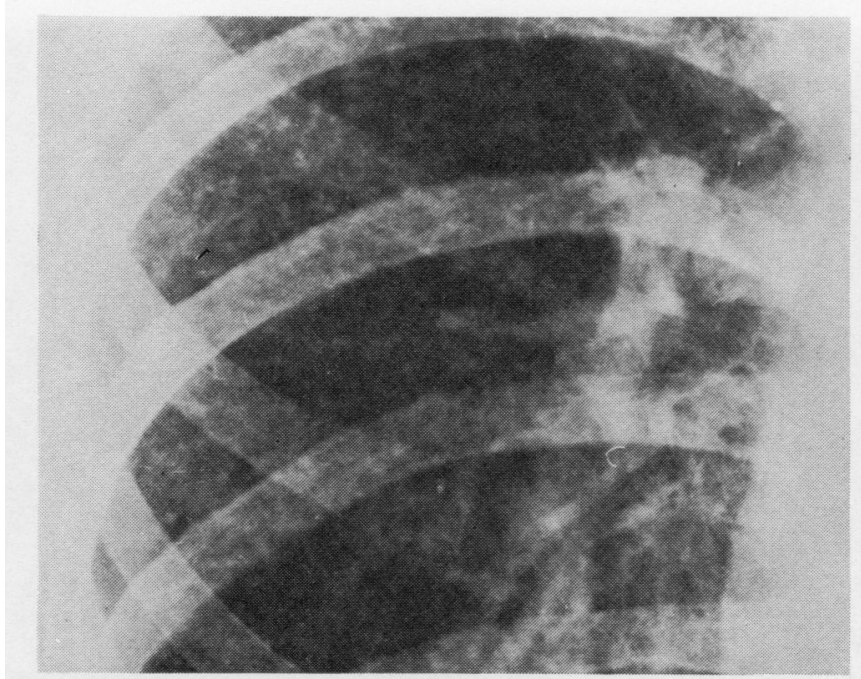

(b)

FIG. 1. Chest radiograph (a) and close-up view (b) showing diffuse miliary mottling in lung fields. 
T A B L E I

PULMONARY FUNCTION TESTS

\begin{tabular}{|c|c|c|}
\hline & & Predicted Normal ${ }^{1}$ \\
\hline $\begin{array}{l}\text { FEV }_{1}(1 . \text { ATPS }) \\
\text { FVC }(1 . \text { ATPS }) \\
\text { FEV } / \text { FEV (\%) } \\
\text { TLC }(1 \text { ATPS) } \\
\text { RV }(1 \text {. ATPS }) \\
\text { TF }\left(\mathrm{mmol} \mathrm{min}^{-1} \mathrm{kPa}^{-1}\right) \\
\mathrm{PaO}_{2}(\mathrm{kPa}) \\
\mathrm{PaCO}_{2}(\mathrm{kPa})\end{array}$ & $\begin{array}{r}3 \cdot 34 \\
3 \cdot 75 \\
92 \\
5 \cdot 90 \\
2 \cdot 25 \\
7 \cdot 4 \\
11 \cdot 3 \\
4 \cdot 8\end{array}$ & $\begin{array}{c}4 \cdot 27 \\
5 \cdot 12 \\
84 \\
6 \cdot 75 \\
1 \cdot 62 \\
12 \cdot 8 \\
13 \cdot 7 \\
4 \cdot 5-6 \cdot 0\end{array}$ \\
\hline
\end{tabular}

${ }^{1}$ Predicted normal from Cotes (1968) for lung volumes and TF, and from Diament and Palmer (1969) for $\mathrm{PaO}_{2}$ and $\mathrm{PaCO}_{2}$.

depression. These nodules were not seen on the parietal pleura, mediastinal lymph nodes were not enlarged, and the liver felt normal through the diaphragm. A small specimen was taken from the anterior portion of the apical segment of the lower lobe.

HISTOLOGY OF LUNG BIOPSY SPECIMEN The cytological characteristics of the tumour cells in the lung (Fig. 3) are identical with those in the neck, although secretory granules are more readily identified. The tumour grows into, and replaces, alveolar spaces, and there is involvement of bronchioles with destruction of the respiratory epithelium (Fig. 4). The stroma is abundant and in many areas contains amyloid fibrils which were positive to Congo red and produced classical greenish birefringence when examined between crossed polarizing filters (Fig. 5a, b).

Occasional mitotic figures are present and many nuclei are solid, showing marked hyperchromatism. This bilateral tumour is clearly an adenocarcinoma of low-grade malignancy, showing lymphatic permeation, and has the appearance of a multifocal peripheral bronchial 'adenoma' of $\overrightarrow{0}$ carcinoid type.

HISTOCHEMISTRY OF LUNG BIOPSY SPECIMEN The results of the histochemical techniques are summarized in Table II. The amyloid fibrils in the stroma did not contain tryptophan residues. The granules were metachromatic when stained with

T A B L E I I

RESULTS OF HISTOCHFMICAL TESTS ON LUNG BIOPSY SPECIMEN

\begin{tabular}{|c|c|c|c|}
\hline Procedure & $\begin{array}{c}\text { Cytochemical } \\
\text { Feature } \\
\text { Demonstrated }\end{array}$ & Result & Reference \\
\hline Congo red & Amyloid & + & $\underset{(1962)}{\text { Puchtler et al. }}$ \\
\hline DMAB nitrite & Tryptophan & 0 & Adams (1957) \\
\hline $\begin{array}{l}\text { Masked } \\
\text { metachromasia }\end{array}$ & $\begin{array}{l}\text { Side-chain } \\
\text { carboxyl groups }\end{array}$ & + & $\begin{array}{l}\text { Solcia et al. } \\
\quad(1968)\end{array}$ \\
\hline $\begin{array}{l}\text { Lead } \\
\text { haematoxylin }\end{array}$ & $\begin{array}{l}\text { Tumour cell } \\
\text { granules }\end{array}$ & + & $\begin{array}{l}\text { Solcia et al. } \\
\quad(1969)\end{array}$ \\
\hline Silver reduction & $\begin{array}{c}\text { Tumour cell } \\
\text { granules }\end{array}$ & 0 & $\begin{array}{l}\text { Sevier and } \\
\text { Munger (1965) }\end{array}$ \\
\hline
\end{tabular}

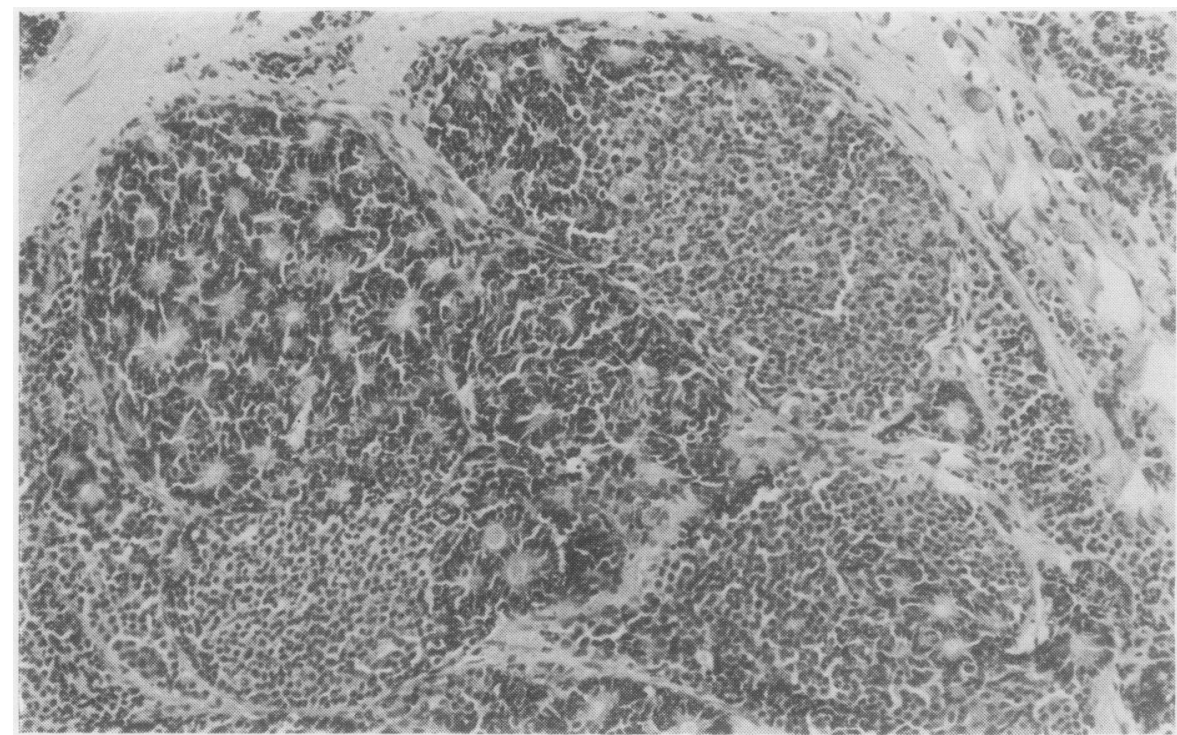

FIG. 2. Biopsy specimen from the neck consists of diffuse groups of cells with indistinct borders and clumps of cells with a rosette appearance. The stroma contains amorphous calcified structures (upper right) (Haematoxylin and eosin $\times 125$ ). 
toluidine blue after hydrolysis in hot hydrochloric acid (Fig. 6). (This test, usually referred to as masked metachromasia, is fairly specific for the polypeptides present in granules of APUD cells or mast cells, and depends on the high content of carboxyl side groups within such granules.)
Many, but not all, tumour cell granules stained with the lead haematoxylin method. The absence of silver reduction is attributed to the use of routine fixation in $10 \%$ neutral buffered formalin which does not retain diffusible phenolic substances.

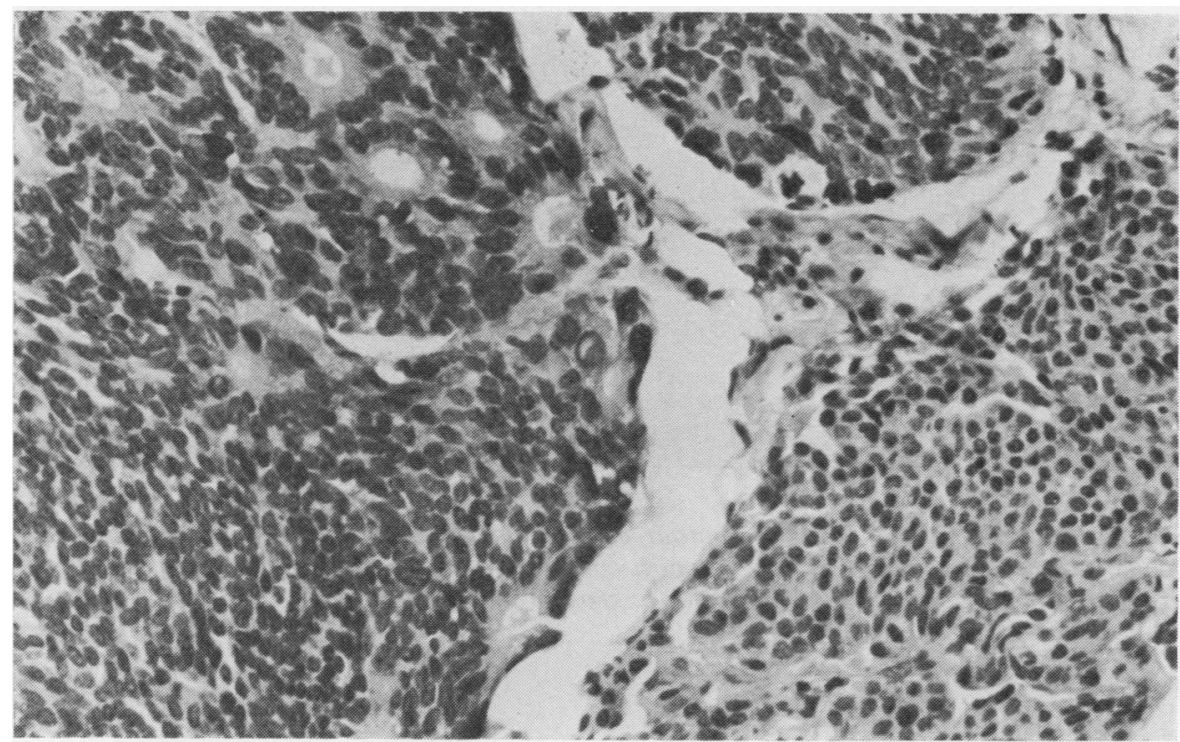

FIG. 3. Biopsy specimen from the lung contains the same two cytological patterns as the specimen from the neck ( $H$ and $E \times 310)$.

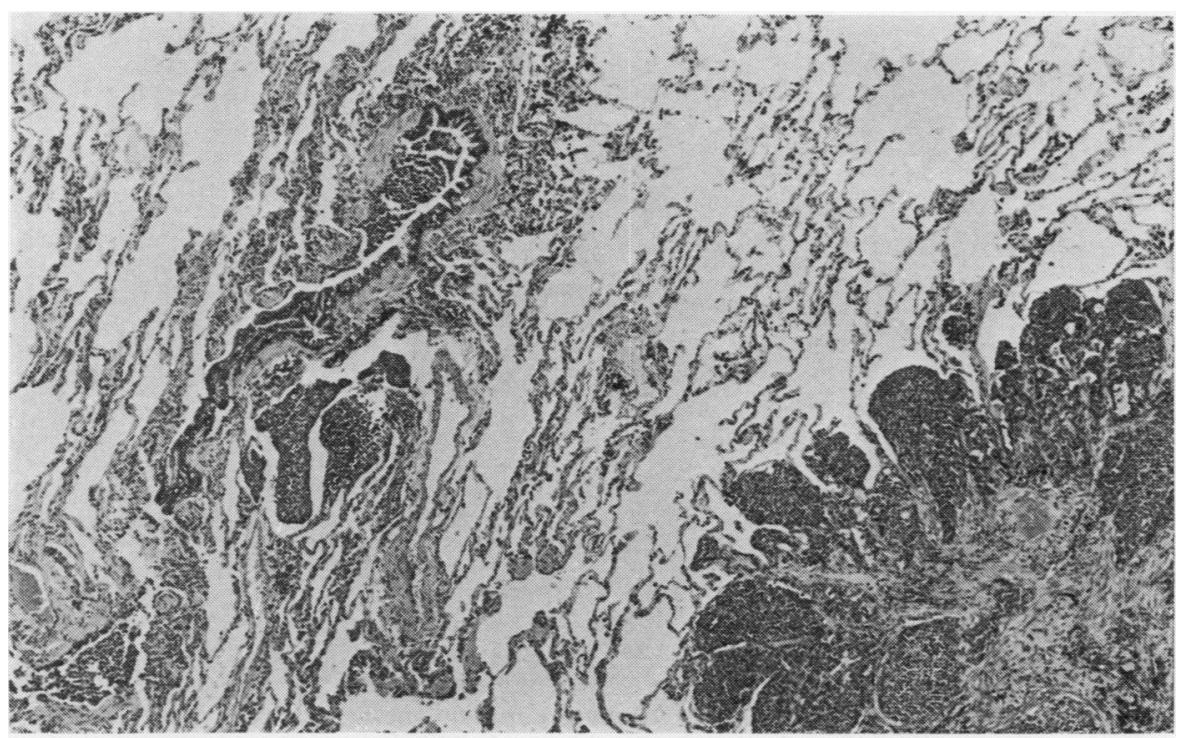

FIG. 4. The tumour fills alveolar spaces and involves the mucosa of a bronchiole ( $H$ and $E \times 50$ ). 


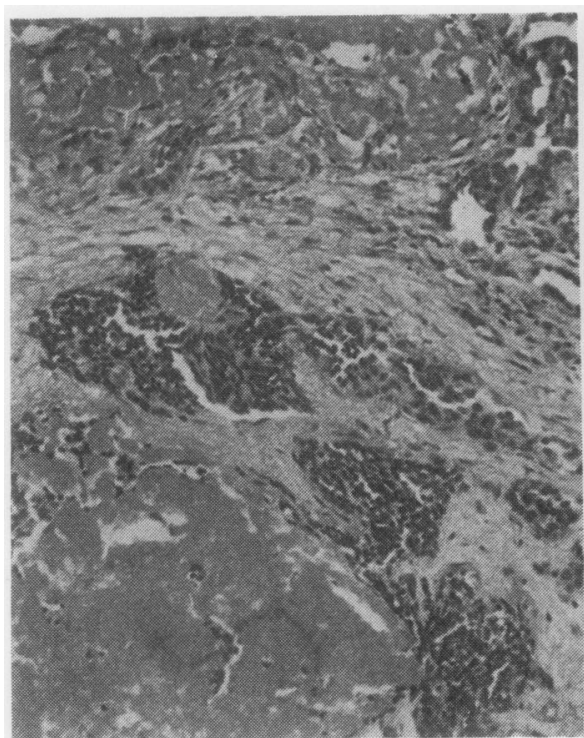

(a)

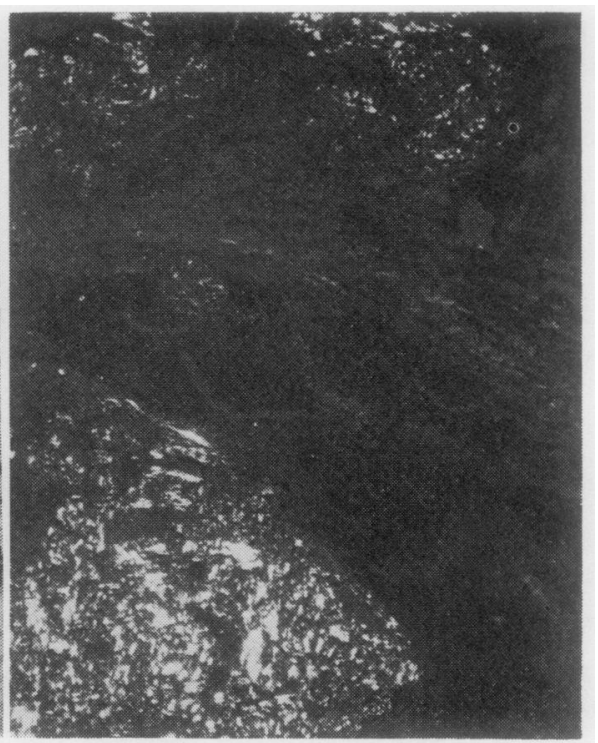

(b)

FIG. 5. The stroma of the lung tumour contains Congo red positive amyloid fibrils (a) which are birefringent (b) with a greenish colour (seen as white areas in the photomicrograph). Congo red (a: transmitted light; b: crossed polarizing filters) $\times 125$.

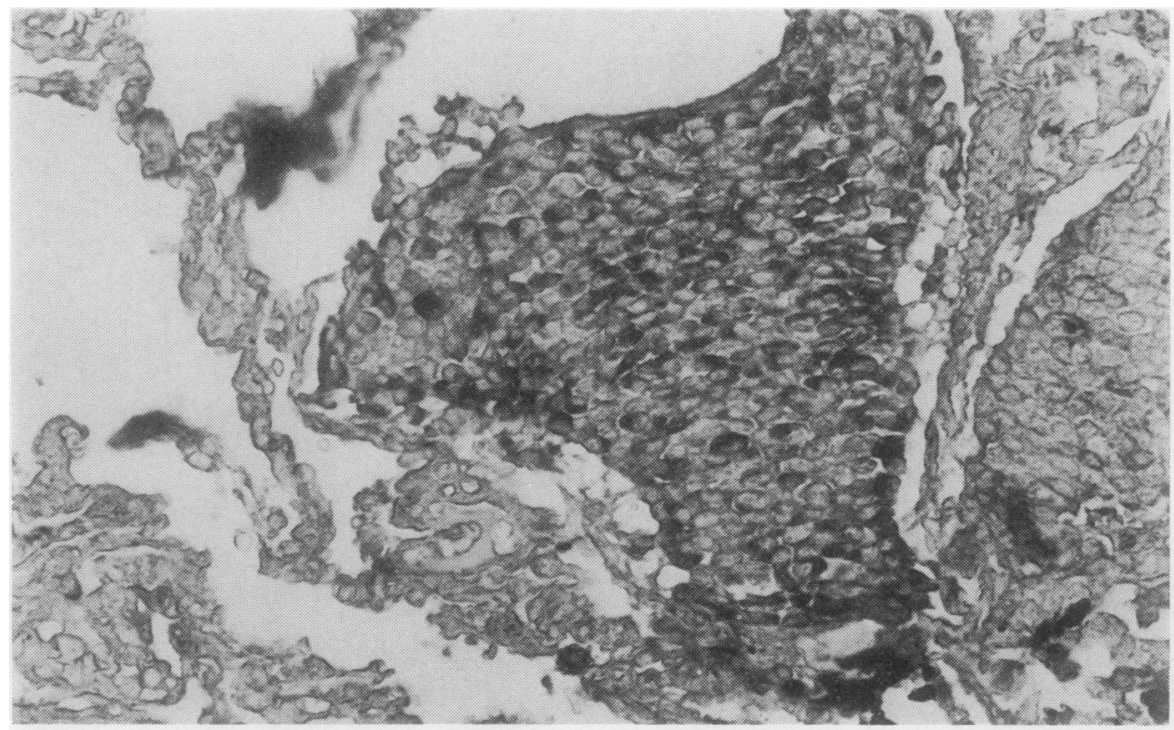

FIG. 6. The cytoplasm of the lung tumour contains metachromatic granules when stained with toluidine blue due to 'unmasking' of side-chain carboxyl groups during acid hydrolysis. Masked metachromasia $\times 310$. 
PROGRESS The patient has been followed up for two years. He has had melphalan intermittently but the drug has produced thrombocytopenia on several occasions, requiring temporary cessation of therapy and resumption at a lower dose. Serial chest radiographs and pulmonary function tests show no change and his general condition remains good. He has developed no skin changes, bronchoconstriction or cardiac valve lesions. Diarrhoea remains well controlled on symptomatic therapy. He had spontaneous left pneumothoraces in April 1974 and February 1975, the latter requiring intercostal drainage. Estimation of urinary 5hydroxy indole acetic acid (5 HIAA) showed a slight excess in September 1974 although no excess had been found in several previous urine specimens.

\section{DISCUSSION}

Diffuse lung changes of miliary type due to a primary carcinoid tumour of lung have not previously been described. Our patient presented with diarrhoea, but without respiratory symptoms, and this was attributed to secretory products from the cells of a primary pulmonary tumour. There was no evidence of an argentaffinoma of the small bowel on barium meal and follow-through examination.

A primary pulmonary tumour of similar histological appearance was reported by Gordon et al. (1973). These authors emphasized the similarity to medullary carcinoma of thyroid and described the appearances as a medullary carcinoma of lung. Their patient was also male, but older than ours; he presented with a long history of recurrent respiratory infections and showed a more coarsely nodular type of pulmonary change with gross, bilateral, hilar lymph node involvement.

From the histological viewpoint, the combination of a typical solid alveolar structure with rosette formation is unusual in a bronchial carcinoid. This combined pattern is found in primary carcinoid tumours of the thymus (Rosai and Higa, 1972; Lowenthal et al., 1974) but the absence of mediastinal changes in the chest radiograph would seem to preclude an origin from the thymus in the present case.

The cell of origin of this lung tumour is undoubtedly the 'parakrine' system of clear cells described by Feyrter (1938). This system of cells, found in many mucosal surfaces throughout the mammalian body, has been cytologically characterized by Pearse (1969) and is referred to as the APUD system. Several of the cell types in the APUD series have been clearly identified as neural crest derivatives (Le Douarin and Le Lièvre, 1970; Pearse and Polak, 1971; Polak, et al., 1974).

Cells in the human bronchial epithelium possessing the characteristics of APUD have been described in fetal lungs (Lauweryns and Peuskens, 1969; Rosan and Lauweryns, 1971; Hage, 1972a, 1972b; Hage, 1973a). Similar cells, which will decarboxylate levodopa, are present in adult human lung (Hage, 1973b), but these cells were identified in biopsies of specimens from a proximal bronchus, and their distribution throughout the adult lung has not been determined. Nevertheless cells with neurosecretory type granules have been demonstrated in bronchiolar epithelium from a patient with multiple peripheral adenomata of lung (Gmelich, Bensch, and Liebow, 1967), and such cells can be assumed to be the source of peripheral oat-cell carcinomata or of peripheral adenomata (Bensch, Corrin, Pariente, and Spencer, 1968). Certainly hilar bronchial adenomata possess typical neurosecretory granules at the ultrastructural level (Bensch et al., 1968) which will reduce silver salts.

Many tumours of the APUD cell system (apudomas) are known to be associated with the deposition of stromal amyloid (apudamyloid). This association is well recognized in medullary carcinoma of thyroid (Hazard, Hawk, and Crile, 1959; Williams, Brown, and Doniach, 1966) and has been described in hilar carcinoid bronchial adenomata (Štěrba, 1968). Amyloid in apudomas is considered to be due to deposition of prohormone derivatives (Pearse, Ewen, and Polak, 1972), and a close association between granules and amyloid fibrils has been demonstrated in medullary carcinoma of thyroid (Meyer, Hutton, and Kenny, 1973).

Apudamyloid and immunamyloid can be conveniently separated on histochemical grounds by the presence, or absence, of demonsirable tyrosine and tryptophan (Pearse et al., 1972), although intrafollicular amyloid in parathyroid glands does not have a constant tryptophan content (Anderson and Ewen, 1974). The lack of histochemically demonstrable tryptophan in the amyloid of the present case is evidence of the APUD cell origin of the tumour.

The amine content of the tumour cells could not be demonstrated by formaldehyde-induced fluorescence as both specimens had been fixed in dilute buffered formalin with consequent loss of any fluorescent quinonoid. The presence of other secretory products in the granules was sought, and 
the positive masked metachromasia of tumour cells indicates a high density of side chain carboxyl groups with a random coil configuration (Bussolati, Rost and Pearse, 1969). APUD cells typically contain polypeptide hormones, or their precursors, which are presumed to be stained after acid hydrolysis (Solcia, Vassallo and Capella, 1968; Pearse, 1970).

The presence of excess 5HIAA in ürine indicates that the tumour is capable of producing excessive 5-hydroxytryptamine, and thus it was assumed that the tumour might possess a membrane-bound aromatic amino acid decarboxylase. It was this contention which prompted the therapeutic use of melphalan in an attempt to achieve high intracellular levels of the cytotoxic agent within tumour cells. Previous experience with the DL-isomer of melphalan (merphalan or L-sarcolysin) in metastatic neuroblastoma has been disappointing (Fernbach et al., 1968), presumably due to loss of specific decarboxylating enzyme systems in highly malignant tumours, although melphalan has been effective in the carcinoid syndrome (Lotito and Mengel, 1969). In the present case the tumour apparently retained many of the cytochemical characteristics of a benign tumour and thus concentration of cytotoxic drug within tumour cell cytoplasm could occur. Results of therapy are difficult to assess objectively but lung function tests and radiographic appearances have not shown any significant deterioration over a period of two years.

We are grateful to Dr. W. R. Gauld for permission to publish details of this patient and to Mr. F. J. S. Gowar for the lung biopsy.

\section{REFERENCES}

Adams, C. W. M. (1957). A p-dimethylaminobenzaldehyde-nitrite method for the histochemical demonstration of tryptophane and related compounds. Journal of Clinical Pathology, 10, 56.

Anderson, T. J. and Ewen, S. W. B. (1974). Amyloid in normal and pathological parathyroid glands. Journal of Clinical Pathology, 27, 656.

Bensch, K. G., Corrin, B., Pariente, R., and Spencer, H. (1968). Oat-cell carcinoma of the lung: its origin and relationship to bronchial carcinoid. Cancer, 22, 1163.

Bussolati, G., Rost, F. W. D., and Pearse, A. G. E. (1969). Fluorescence metachromasia in polypeptide hormone-producing cells of the APUD series, and its significance in relation to the structure of the precursor protein. Histochemical Journal, 1, 517.
Cotes, J. E. (1968). Lung Function, 2nd edition, p. 384. Blackwell, Oxford.

Diament, M. L. and Palmer, K. N. V. (1969). Dynamic and static volumes and blood-gas tensions in bronchial asthma. Lancet, 1, 591.

Fernbach, D. J., Haddy, T. B., Holcomb, T. M., ® Stuckey, W. J., Jr., Sullivan, M. P., and Watkins, ڤ్ W. L. (1968). L-sarcolysin (NSC-8806) therapy for children with metastatic neuroblastoma. Can- ? cer Chemotherapy Reports, 52, 293.

Feyrter, F. (1938). Über diffuse endokrine epitheliale $\vec{\omega}$ Organe. J. A. Barth, Leipzig.

Gmelich, J. T., Bensch, K. G., and Liebow, A. A. $\stackrel{x}{ }$ (1967). Cells of Kultschitzky type in bronchioles and their relation to the origin of peripheral car- is cinoid tumor. Laboratory Investigation, 17, 88. iv

Gordon, H. W., Miller, R., Jr., and Mittman, C. $\vec{N}$ (1973). Medullary carcinoma of the lung with 을 amyloid stroma: a counterpart of medullary carcinoma of the thyroid. Human Pathology, 4, 431.

Hage, E. (1972a). Electron microscopic identification of endocrine cells in the bronchial epithelium of human foetuses. Acta Pathologica et Micro- $\vec{\theta}$ biologica Scandinavica, 80A, 143.

(1972b). Endocrine cells in the bronchial mucosa of human foetuses. Acta Pathologica et Microbiologica Scandinavica, 80A, 225.

(1973a). Electron microscopic identification of $\bar{\partial}$ several types of endocrine cells in the bronchial epithelium of human foetuses. Zeitschrift für $\stackrel{\square}{\circledR}$ Zellforschung und mikroskopische Anatomie, 141, 401 .

(1973b). Amine-handling properties of APUDcells in the bronchial epithelium of human foetuses and in the epithelium of the main bronchi of human adults. Acta Pathologica et Microbiologica Scandinavica, 81A, 64.

Hazard, J. B., Hawk, W. A., and Crile, G. Jr. (1959). ્ֻટ Medullary (solid) carcinoma of thyroid: a clinicopathologic entity. Journal of Clinical Endocrinology, 37, 205.

Lauweryns, J. M. and Peuskens, J. C. (1969). Argyrophil (kinin and amine producing?) cells in human infant airway epithelium. Life Sciences, 을 $8,577$.

Le Douarin, N. and Le Lièvre, C. (1970). Demonstra- $\frac{7}{O}$ tion de l'origine neurale des cellules à calcitonine du corps ultimobranchial chez l'embryon de $\mathrm{N}$ Poulet. Comptes Rendus Hebdomadaires des Séances de l'Academie des Sciences, Series D. O 270, 2857.

Lotito, C. A. and Mengel, C. E. (1969). Effect of $\sigma$ melphalan in the malignant carcinoid syndrome. Archives of Internal Medicine, 124, 36.

Lowenthal, R. M., Gumpel, J. M., Kreel, L., Mc- 尽 Laughlin, J. E., and Skeggs, D. B. L. (1974). Carcinoid tumour of the thymus with systemic manifestations: a radiological and pathological $\stackrel{\vec{D}}{\circ}$ study. Thorax, 29, 553.

Meyer, J. S., Hutton, W. E., and Kenny, A. D. (1973). Medullary carcinoma of thyroid gland. Sub- 응 cellular distribution of calcitonin and relationship between granules and amyloid. Cancer, 31, 433. 
Pearse, A. G. E. (1970). The characteristics of the C cell and their significance in relation to those of other endocrine polypeptide cells and to the synthesis, storage and secretion of calcitonin. In Calcitonin 1969: Proceedings of the 2nd International Symposium, edited by S. Taylor, p. 125. Heinemann, London.

(1969). The cytochemistry and ultrastructure of polypeptide hormone-producing cells of the APUD series and the embryologic, physiologic and pathologic implications of the concept. Journal of Histochemistry and Cytochemistry, 17, 303.

, Ewen, S. W. B., and Polak, J. M. (1972). The genesis of apudamyloid in endocrine polypeptide tumours: Histochemical distinction from immunamyloid. Virchows Archiv Abteilung B. Zellpathologie, 10, 93.

and Polak, J. M. (1971). Cytochemical evidence for the neural crest origin of mammalian ultimobranchial C cells. Histochemie, 27, 96.

Polak, J. M., Pearse, A. G. E., Le Lièvre, C., Fontaine, J., and Le Douarin, N. M. (1974). Immunocytochemical confirmation of the neural crest origin of avian calcitonin-producing cells. Histochemistry, 40, 209.

Puchtler, H., Sweat, F., and Levine, M. (1962). On the binding of congo red by amyloid. Journal of Histochemistry and Cytochemistry, 10, 355.

Robin, E. D. (1970). In Harrison's Principles of Internal Medicine, 6th edition, edited by $M$. M. Wintrobe, G. W. Thorn, R. D. Adams, I. L. Bennett Jr., E. Braunwald, K. J. Isselbacher, and R. G. Petersdorf, p. 1301. McGraw Hill, New York.
Rosai, J. and Higa, E. (1970). Primary mediastinal carcinoid tumor: clinicopathologic study of seven cases. (Abstract.) Laboratory Investigation, 22, 508.

- and - (1972). Mediastinal endocrine neoplasm, of probable thymic origin, related to carcinoid tumour. Clinicopathologic study of 8 cases. Cancer, 29, 1061.

Rosan, R. C. and Lauweryns, J. M. (1971). Secretory cells in the premature human lung lobule. Nature, 232, 60 .

Sevier, A. C. and Munger, B. L. (1965). A silver method for paraffin sections of neural tissue. Journal of Neuropathology and Experimental Neurology, 24, 130.

Solcia, E., Capella, C., and Vassallo, G. (1969). Lead haematoxylin as a stain for endocrine cells. Histochemie, 20, 116.

-_, Vassallo, G., and Capella, C. (1968). Selective staining of endocrine cells by basic dyes after acid hydrolysis. Stain Technology, 43, 257.

Stěrba, J. (1968). Metastasierendes Bronchialkarzinoid mit Amyloid im Stroma. Zentralblatt für allgemeine Pathologie und pathologische Anatomie, 111, 555 .

Williams, E. D., Brown, C. L., and Doniach, I. (1966). Pathological and clinical findings in a series of 67 cases of medullary carcinoma of the thyroid. Journal of Clinical Pathology, 19, 103.

Requests for reprints to: Dr. S. W. B. Ewen, Department of Pathology, University Medical Buildings, Foresterhill, Aberdeen AB9 2ZD. 